\title{
The Comparison of the Question Types in the RQA (Reading, Questioning, and Answering) Learning Model and Conventional Learning Model
}

\author{
${ }^{1,2}$ Slamet Hariyadi, ${ }^{3 *}$ Aloysius Duran Corebima, ${ }^{3}$ Siti Zubaidah, ${ }^{3}$ Ibrohim \\ ${ }^{1}$ Postgraduate Student of Universitas Negeri Malang, Indonesia \\ ${ }^{2}$ Faculty of Teacher's Training and Education, University of Jember, Indonesia \\ ${ }^{3}$ Faculty of Mathematics and Natural Science, Universitas Negeri Malang, Indonesia
}

\begin{abstract}
The purpose of this study was to observe the types of questions in the learning interaction to determine the distribution of cognitive, knowledge and cross section dimension. The subjects of the study were 64 students of the Genetics course with the age between 18-20 years old. The data is taken as a question frequency (percentage) of questions arising through the observation in the RQA and conventional class based on Bloom's taxonomy of Krathwohl version. Related to the cognitive dimension, $Q_{2}$ (Understand) question obtains the highest frequency $(34,91 \%)$ in the RQA class but in the conventional class $Q_{1}$ (Remember) question obtains the highest one (47.62\%). Related to the knowledge dimension the frequency of the $Q_{C}$ (Conceptual) question obtained is the highest one (40.57\%) in RQA class but in the conventional class the frequency of the $Q_{F}$ (Factual) question is the highest one (44.44\%). Related to the cross section between cognitive and knowledge dimension, the frequency of the Classify question is the highest one in the RQA class (18.87\%), whereas in the conventional class the highest frequency is belonged to the List question (25.40\%). The RQA learning model is suggested to be used in the genetics course because it's better potency than the conventional learning.
\end{abstract}

Keywords: Cognitive Dimension, Conventional Learning, Knowledge Dimension, Learning Model, ReadingQuestioning-Answering

\section{INTRODUCTION}

21 st Century is signed by the huge influence of information technology and communication in various aspects of life, so the 21st century is known as the age of information. The boundaries and barriers among countries are becoming increasingly blurred and citizens converge into one large community as global citizens, so the present era is also called as the global era. The existence of this technology has changed the way people transact, interact, communicate, including the way people learn. This condition provides space for the people to be able to obtain any information, from anywhere and anytime. The impact will affect on the learning in society that can construct the learning patterns anytime, anywhere, with anyone, in any way with any material. Learning is more open, flexible and spread. Therefore, educators and students should be ready to respond to such major changes. There are four things proposed by Greenstein (2012) in synergizing learning with 21st century challenges, namely tool (Information and Technology), working (communication and collaboration), thinking (creativity, critical thinking, problem solving and metacognition), and living Citizen (life skills and personal responsibility to live in the world).

The demands of these indicators have an implication toward the necessity of innovation related to the elements of approach, models, strategies, methods, techniques, and tactics of learning to synergize with these needs. According to Zhakhina et al. (2016) educational innovation was required to comply with the dynamic development of the time, including the elements of the process and practice of education. Insyasiska et al. (2015) argued that education in the 21 st century should be able to build the students' intelligence capability in order to solve existing problems. In this relation, the 'approach' considered should be able to respond to the challenges orienting on student centered learning, because it internally induces students to change their mindset and improve their self-motivation. The required 'model' is a model pattern that synergizes the various methods and strategies, so that students are active in the learning interaction. The expected 'strategy' is ralated to the implementation of effective 
steps that can accelerate students to absorb knowledge quickly. The desired 'method' is the effective ways to be implemented during the learning. 'Technique' is a certain way of a teacher designing a model or a method based on his own experiences. 'Tactics' is a special trick of teachers to develop appropriate steps in relation with the uniqueness of the students.

On the other hand, there is one item of learning activities which becomes strategic key and often appears in the learning activities, and can cover the needs of 21 st century challenges, namely the questioning skills. Questioning is one of the elements which are needed in the learning activities, especially as an evaluation tool (Omar et al. 2012) to know the level of mastery of knowledge, both those which have not been taught and those which have been taught. Questioning is a skill required from the beginning of the lesson, during the main activities, and up to the closing activities.

The changing times are also responded by the world education leaders. In the early 21 st century Anderson et al. (2001) together with Krathwohl (2002) sparked new perspectives on Taxonomy of Learning (Taxonomy of Educational Objectives) written in 1949 and published in 1956 by Benjamin $\mathrm{S}$. Bloom. Changes concern with the meaning of the operational word that has been used as a guide in designing learning objectives. Bloom never selects every operational word as a form of nouns and verbs. Therefore, Krathwohl had made classification of the taxonomy of learning in two different dimensions, namely cognitive dimension and knowledge dimension. Cognitive dimension covers remember, understand, apply, analyze, evaluate and create. While the knowledge dimension covers factual, conceptual, procedural and metacognitive element. One interesting thing of this change is the emergence of metacognition as the highest element of the knowledge dimension.

To date, questioning activity is only considered as a complement to learning in the conventional class of many educational institutions. It is usually done at the beginning of learning, as a form of apperception. During the main learning activities, it is often given to inquire about unclear material during the lesson. This questioning activity is repeated in the closing activity to confirm whether or not all the material has been understood. In fact, questioning has a very broad role, not just for checking about the students' knowledge or to check and recheck the students' understanding toward the learning material that has been delivered. Questioning can be used as a guide for understanding concepts, digging up the previously known knowledge, connecting the ideas among different students, triggering new ideas or opinions, and so on.

One of the learning models that accommodates the questioning activity is RQA learning model (Reading, Questioning, Answering). This model is intentionally created to provide the students' initial knowledge before entering the classroom, and to trigger them to arrange questions and answers independently. The first syntax done by the students is to summarize the material that has been determined into a brief summary but containing the essence of the material. Based on this acivity, students are asked to make questions about the material that had not been understood yet during the summarizing process, or if they have any idea related to the arranged concept needed to be elaborated. These questions are answered by the students based on their knowledge. After that, all these work are submitted before the class began (Corebima \& Bahri, 2011).

In relation to the above explanation, it is necessary to analyze the types of questions in the learning models implemented through the questions presented by the students during the teaching and learning activities. This study was conducted in order to analyze the types of questions in the lecture implementating the RQA learning model, compared to those in the lecture implementating conventional learning.

\section{Materials \& Methods}

The research was conducted in biology education program, Faculty of Teacher Training and Education University of Jember, Indonesia, by using qualitative and quantitative approach. Subjects of this research were third semester students with the age between 18-20 years old, programming in the Genetics course in the odd semester of 2015/2016 academic year. The total subjects were 64 students divided into two classes: 31 students in class A (control group) and 33 students in class B (experiment class).

The research was conducted with the purpose of observing the types of questions in the learning interaction to determine the distribution of cognitive dimension, knowledge dimension and the cross section dimension. The obtained data were in the form of the frequency (percentage) of questions that 
arised through the activity of direct observation in the classroom through the implementation of RQA learning model and conventional learning model. Every question arised was separately tabulated based on the types of the questions. The results of the tabulated data and its analysis were described based on Bloom's taxonomy of Krathwohl version (2002) in the cognitive dimension of remember $\left(Q_{1}\right)$, understand $\left(Q_{2}\right)$, apply $\left(Q_{3}\right)$, analyze $\left(Q_{4}\right)$, evaluate $\left(Q_{5}\right)$, create $\left(Q_{6}\right)$ and knowledge dimension of factual $\left(Q_{f}\right)$, conceptual $\left(Q_{c}\right)$, procedural $\left(Q_{p}\right)$, metacognitive $\left(Q_{m}\right)$ as well as the cross-section dimension (between the cognitive dimension and knowledge dimension).

\section{RESUlTS \& DiscusSiON}

\subsection{Results}

The results of this research show an interconnected frequency pattern in the RQA class and conventional class, between the types of questions of cognitive and knowledge dimension, as well as of the cross section dimension. Question types of cognitive dimension and knowledge dimension are presented in the Table 1 and Table 2 respectively; those of cross section are presented in the Table 3.

Table1. Question Types of Cognitive Dimension

\begin{tabular}{|c|c|c|c|c|c|}
\hline Code & Question Types & RQA (\%) & Order Thinking (\%) & Conventional (\%) & Order Thinking (\%) \\
\hline $\mathrm{Q}_{1}$ & Remember & 29.25 & \multirow{3}{*}{ LOT (74.53) } & 47.62 & \multirow{3}{*}{ LOT $(87.30)$} \\
\hline $\mathrm{Q}_{2}$ & Understand & 34.91 & & 33.33 & \\
\hline $\mathrm{Q}_{3}$ & Apply & 10.38 & & 6.35 & \\
\hline $\mathrm{Q}_{4}$ & Analyze & 12.26 & \multirow{3}{*}{ HOT (25.47) } & 7.94 & \multirow{3}{*}{$\operatorname{HOT}(12.70)$} \\
\hline $\mathrm{Q}_{5}$ & Evaluate & 8.49 & & 4.76 & \\
\hline $\mathrm{Q}_{6}$ & Create & 4.72 & & 0 & \\
\hline
\end{tabular}

Notes. LOT (Lower Order Thinking), HOT (Higher Order Thinking)

Based on the data of cognitive dimension, question type of $Q_{2}$ obtains the highest frequency $(34,91 \%)$ in the RQA class follwed by question type of $Q_{1}, Q_{4}, Q_{3}, Q_{5}$, and $Q_{6}$. These results differed from those found in the conventional class in which question type of $Q_{1}$ obtains the highest frequency $(47.62 \%)$, followed by question types of $Q_{2}, Q_{4}, Q_{3}, Q_{5}$, and $Q_{6}$. The difference of the two classess are related to the order of question types of $Q_{1}$ and $Q_{2}$. Specifically, the $Q_{6}$ question does not appear in the conventional class $(0 \%)$.

From the point of view of thinking level, the data of cognitive dimension question type can be divided into two groups: Lower Order Thinking (LOT) consisting of $Q_{1}, Q_{2}$ and $Q_{3}$ and Higher Order Thinking (HOT) consisting of $Q_{4}, Q_{5}$ and $Q_{6}$ (Brookhart, 2010). The data indicate that the LOT in the RQA class $(74.53 \%)$ is lower than that in the conventional class $(87.30 \%)$. Similarly, the HOT in RQA class (25.47\%) is higher than that in the Conventional class (12.70); even mathematically the value of the HOT in RQA class is twice higher than that of the HOT in conventional class.

Table2. Questions Types of Knowledge Dimension

\begin{tabular}{|l|l|l|l|}
\hline Code & Question Type & RQA (\%) & Conventional (\%) \\
\hline $\mathrm{Q}_{\mathrm{F}}$ & Factual & 19.81 & 44.44 \\
\hline $\mathrm{Q}_{\mathrm{C}}$ & Conpceptual & 40.57 & 31.75 \\
\hline $\mathrm{Q}_{\mathrm{P}}$ & Procedural & 17.92 & 17.46 \\
\hline $\mathrm{Q}_{\mathrm{M}}$ & Metacognitive & 21.70 & 6.35 \\
\hline
\end{tabular}

Related to the knowledge dimensions of RQA class, the the frequency of the $Q_{C}$ type question obtained is the highest one (40.57\%), followed successively by $Q_{M}$ type (21.70\%), $Q_{F}$ type $(19.81 \%)$, and $Q_{P}$ type $(17.92 \%)$. On the other hand, related to the conventional class the highest frequency is belonged to the $Q_{F}$ type (44.44\%), followed by the frequency of $Q_{C}$ type, $(31.75 \%), Q_{P}$ type (17.46\%), and $Q_{M}$ type $(6.35 \%)$ types successively. The data show that the frequency of $Q_{F}$ type in conventional class is twice bigger than that of the RQA class, and conversely the frequency of $Q_{M}$ type in the RQA class is three times bigger than that of the conventional class

Related to the cross section dimension (between the cognitive and knowledge dimensions), the frequency of the classify type is the highest one in the RQA class and that of the identify, integrate, check, generate, assemble and create type are the lowest one, whereas in the conventional class, the highest frequency is belonged to the list type and the lowest frequency are belonged to the reflect, generate, assemble, design and create types. Another interesting point about the data is a striking 


\section{Slamet Hariyadi et.al}

picture related to the $\mathrm{Q}_{6}$ row which shows that in the RQA class there are some questions yet asked by the students even in low frequencies, but no questions appeared in the conventional class. Similarly, in the metacognitive column, the total questions that appeared in the RQA class were $21.69 \%$, while the total question on the conventional class were only $6.36 \%$, or one third of the RQA class.

Table3. The Frequencies of Question Types related to the of Cross Section of the Cognitive and Knowledge Dimension

\begin{tabular}{|l|l|l|l|l|l|}
\hline Kode & $\mathrm{F}(\%)$ & $\mathrm{C}(\%)$ & $\mathrm{P}(\%)$ & $\mathrm{M}(\%)$ & \\
\hline Q1 & 10.38 & 12.26 & 5.66 & 0.94 & RQA \\
\hline & 25.40 & 15.87 & 4.76 & 1.59 & Conventional \\
\hline & List & Recognize & Recall & Identify & \\
\hline Q2 & 3.77 & 18.87 & 5.66 & 6.60 & RQA \\
\hline & 14.29 & 9.52 & 7.94 & 1.59 & Conventional \\
\hline & Summarize & Classify & Clarify & Predict & \\
\hline Q3 & 1.89 & 3.77 & 1.89 & 2.83 & RQA \\
\hline & 1.59 & 1.59 & 1.59 & 1.59 & Conventional \\
\hline & Respond & Provide & Carry Out & Use & \\
\hline Q4 & 1.89 & 1.89 & 0.94 & 7.55 & RQA \\
\hline & 1.59 & 3.17 & 1.59 & 1.59 & Conventional \\
\hline & Select & Differentiate & Integrate & Deconstruct & \\
\hline Q5 & 0.94 & 2.83 & 1.89 & 2.83 & RQA \\
\hline & 1.59 & 1.59 & 1.59 & 0.00 & Conventional \\
\hline & Check & Determine & Judge & Reflect & \\
\hline Q6 & 0.94 & 0.94 & 1.89 & 0.94 & RQA \\
\hline & 0.00 & 0.00 & 0.00 & 0.00 & Conventional \\
\hline & Generate & Assemble & Design & Create & \\
\hline
\end{tabular}

\subsection{Discussion}

\subsubsection{Cognitive Dimenssion Questions}

The frequency of $Q_{2}$ question (undersand) in the RQA class is the highest one compared to the other types of questions. This condition is related to the fact that in the RQA learning the students are required to make a summary (resume) before attending the learning process, thus triggering the need for in-depth understanding of genetic concepts. In contrast, the students in the conventional class are only encouraged to read the material before coming to class without composing a resume, so the $Q_{1}$ question (remember) is more dominant than the others. It shows that many of the basic concepts of genetics require more detailed explanation before its understanding in depth $\left(Q_{2}\right)$. According to Krathwahl (2002), the $Q_{1}$ questions attempt to retrieve the relevant knowledge from the long-term memory, whereas $Q_{2}$ questions attempt to get the meaning of the subject matter, whether by oral, written or graphical communication.

In the thinking level perspective, the frequency of Lower Order Thinking (LOT) in the conventional class is higher than that in the RQA class, but conversely, the frequency of Higher Order Thinking (HOT) in the RQA class is higher than that in the conventional class (Table 1). This suggests that the RQA class provides conditions that trigger high-order thinking skills. The reading phase on the RQA implemented by preparing a summary has opened the students' horizones to master the concept; followed by the questioning phase that makes the students experience cognitive process of accepting (placing a concept on the students' cognitive framework) and challenging (enabling the concepts that have been formed be strongly linked). The final phase of answering induce the students to develop the metacognitive skills by adapting various learning strategies to meet the demands of the task (Sumampouw, 2011). All of these phases have empowered the students' high-order thinking skills.

Other types of questions show the same sequence of the frequency of the questions related to the cognitive and knowledge domains, namely $Q_{4}, Q_{3}, Q_{5}$ and $Q_{6}$. Based on the description of Mayer (2002), $Q_{4}$ question appears from a complete understanding obtained from the previous questions. Then, from the answers obtained, the $Q_{3}$ question is produced to be implemented on the existing concepts. The result may induce the $Q_{5}$ question to assess the validity and consistency of the existing concepts. This condition triggers the $Q_{6}$ question as a form of high-order thinking. The distribution of these questions is highly dependent on the interaction patterns of learning. If the interaction puts more emphasis on the disclosure of definitive facts, the $Q_{1}$ questions appear more often. If the concept 
understanding is more dominant, the $Q_{2}$ questions appear more often. In practice-based learning, the $Q_{3}$ questions appear more frequently. This fact is consistent with the observation and recording of Magas et al. (2017) on 12 laparoscopic cholecystectomy surgery in the operating room, producing the type and level of intraoperative questions in all cases. From the 141 questions arised, there were 43 $Q_{1}, 29 Q_{2}, 47 Q_{3}, 13 Q_{4}, 8 Q_{5}$ and $0 Q_{6}$ questions. On the other hand, in the Medical Anatomy course there are $27 Q_{1}, 25 Q_{2}, 14 Q_{3}, 31 Q_{4}, 1 Q_{5}$ and $10 Q_{6}$ questions (Phillips et al., 2013).

The phenomena of the conventional class that raise more Lower Order Thinking questions is related to the implemented learning methods. The discussion method and the presentation that were given provide the opportunities for the students to do questioning and answering, but there was not any prelearning phase that required the students to read the material to be learned, only the students' selfawareness to prepare the learning based on the course syllabus. This condition makes the questions arise spontaneously during the learning process, with the question types ranging from remember, understand and apply types. According to Krathwahl (2002) the remembering phase is less complex than the understanding phase, and the understanding phase is less complex than then applying phase, and so on. This factor further affects on the distribution of the other questions types. Thus, it can be seen that the high order thinking type of questions (marked by question $\mathrm{Q}_{4}-\mathrm{Q}_{6}$ ) in RQA class are more than those in the conventional class.

\subsubsection{Knowledge Dimension Questions}

The $Q_{C}$ questions of the knowledge dimensions in RQA class is more dominant than those of $Q_{F}, Q_{P}$, and $Q_{M}$ questions. Whereas in the conventional class, the $Q_{F}$ question is more dominant than the other types of questions. This fact is in line with that of found in the cognitive dimension, where the RQA class is dominated by $Q_{2}$ question and the conventional class is dominated by $Q_{1}$ question. There is a strong correlation between $Q_{2}$ (understand) and $Q_{C}$ (conceptual) questions. In the $Q_{2}$ (understand) questions, students put more emphasis on a deep understanding of a concept, so it indirectly relates to the $Q_{C}$ (conceptual) question. This type of question reveals more on classifications, categories, models, theories, schemes, and concept interrelation. While the $Q_{1}$ (remember) question puts more emphasis on memory definitions and statements of fact, so that it is linear with the $Q_{F}$ (factual) questions of the knowledge dimensions. This fact is in accordance with the opinions of Munzenmaier \& Rubin (2013) saying that the cognitive processes that occur in the $Q_{1}$ (remember) question (recognize and recall) contain $Q_{F}$ (factual) question; $Q_{2}$ (understand) question contains $Q_{C}$ (conceptual) question; $Q_{3}$ (apply) question contains $Q_{P}$ (procedural) question; $Q_{4}$ (analyze) question, $Q_{5}$ (evaluate) question and $Q_{6}$ (create) question contains metacognitive question.

An interesting thing to be revealed is that the frequency of $\mathrm{Q}_{\mathrm{M}}$ (metacognitive) question in RQA class is larger than that of the $\mathrm{Q}_{\mathrm{F}}$ (factual) and $\mathrm{Q}_{\mathrm{P}}$ procedural question. Even this metacognitive question score is three times higher than that of the conventional class. This condition is caused by the fact that the RQA strategy has effective contributions toward metacognition (Bahri \& Corebima, 2015), can activate metacognition (Bahri, 2010; Sumampouw, 2011; Corebima \& Bahri, 2011), can induce an increase of metacognition (Khairil. 2009), and it is loaded with systematic and planned efforts of metacognition empowerment (Hasanuddin, 2013). When the students were given the task for making a summary (reading phase), they indirectly examined the learning material carefully, and the summaries which were compiled demanded the students to be able to determine the concepts which were more important than those attracted their attention (Coan, 2004). Furthermore, the students created questions (questioning phase) based on the summary which had been compiled, in which the quality of the question types was much influenced by the students' mastery of the learning material. The answering phase demanded the students to answer the questions that they had made by themselves. In line with Arends (2001) the sequence of the RQA phases has formed a thinking pattern about how to think and to use specific learning strategies appropriately, so the metacogntive skills were induced.

According to Livingston (1997) metacognitif is thinking about how to think, where there is an integration between the new knowledge which students received during the phase of RQA and their previous knowledge, so that it produces the interaction of thinking processes. Metacognitive knowledge is also the knowledge of our own cognition and about the ability of oneself in relation to various issues (Anderson et al., 2001). Metacognitive is associated with strategic knowledge, cognitive task and self knowledge (Pintrich, 2002). It means that the summarising task given to the 
RQA class followed by the construction of questions and its answers by the students themselves have induced the students to create interesting ideas with a personal strategy, which elaborates the material from another point of view and solves problems in their own way. This condition is in line with the research results of Bahri (2010), stating that RQA learning could improve students' metacognition as much as $22.77 \%$, and increase the metacognitive skills of low academic students as much as $57.4 \%$ higher than that of the high academic students.

\subsubsection{The Cross-Section Question (Between Cognitive Dimension and Knowledge Dimension)}

The learning process is a combination of cognitive processes and knowledge processes (Anderson et al., 2001). The resultant interaction between the cognitive dimension and knowledge dimension generates new dimension consisting of List, Recognize, Recall, Identify, Summarize, Classify, Clarify, Predict, Respond, Provide, Carry out, Use, Select, Differentiate, Integrate, Deconstruct, Check, Determine, Judge, Reflect, Generate, Assemble, Design and Create.

Based on data presented Table 3, question type of classify has the highest frequency compared to the other qustion types in RQA class. This fact is interesting because the process occured is through summarizing syntax, but the dominant question type is not summarize. According to Heer (2009) summarize question type produces a new perspective from the summarized concept, but the classify question type has been able to combine the concepts massively. Thus, the questions appeared during the research have already involved the processes of detecting the characteristics of the standard concepts to be mixed into a more comprehensive concept. This condition is important in the genetic class because of the frequent misconceptions due to the narrow views of some book authors of genetics. According to Roini et al. (2012) that average of the genetic concepts understood correctly by teachers and senior high school students are $29.8 \%$ and $21.2 \%$ respectively; and according to Hariyadi (2015), maximally the undergraduate students are able to absorb the genetic concepts being taught maximally as much as $75 \%$. Thus, it is a natural one that the genetic class in this research puts more emphasis on the conceptual understanding to avoid misconceptions. On the other hand, in the conventional class, the list question type is more dominant than the others. This fact suggests that in the conventional class questions are used to confirm the concepts already known, to be confronted with the concepts described in the classroom. This condition is one of the disadvantages of conventional learning which carries out discussion activity on each meeting without giving additional tasks to read and solve problems for all students.

The data in Table 3 show an interesting pattern. In the row of $\mathrm{Q}_{6}$ (Create) there is an extreme data difference between the RQA class and the conventional class, in which there are not any questions detected in the conventional class $(0 \%)$, whereas the questions in the RQA class the questions appeared in all columns (4.72\%). This phenomenon appears to be consistent with the data in Table 1 indicating that the conventional class lacks of the good academic atmosphere for the emergence of metacognitive questions. The conceptual unpreparedness before the learning process causes the students to raise check-and-recheck questions toward definitions (remember), deep questions toward a concept (understand) and to ask for examples of the implementation of the concept presented by the presenter (apply). Unlike the RQA class students indirectly urged to read the material beforehand, had prior knowledge as a starting point before the learning process began. In addition, the task of composing questions and answering increasingly broaden the students insights in the learning process. The interaction between the students' prior knowledge and the new knowledge received during learning raises ideas in different perspectives. In other word the syntax of RQA that had been done by the students has triggered the interaction between the concepts being learned and those previously known, so that it creates ideas as a results of the students' own thinking. RQA learning also develops metacognitive skills (Sumampouw, 2011), improves metacognitive awareness and cognitive learning results (Bahri, 2010), empowers metacognitive awareness in a systematic and planned way (Hasanuddin, 2013), improves the average score of all aspects of learning, metacognitive skills individually, and increases performance from the first task until the last task (Corebima, 2014).

\section{Conclusion}

Learning model has a significant efffect on the students' thinking patterns, which indirectly affects the types of questions raised during the classroom learning. Based on the cognitive dimension, the dominance of question type in RQA class is $Q_{2}(34.91 \%)$ and conventional class $Q_{1}(47.62 \%)$, . On the knowledge dimension, the dominance of ths type of question is in RQA class $Q_{C}(40.57 \%)$ and in 
the conventional class is $Q_{f}(44.44 \%)$. The cross section between the cognitive dimension and the knowledge dimension brings up question type of Classify (18.87\%) which is more dominant in RQA class, and List (25.40\%) in the conventional class. Thus, the distribution of question types can be used as the foundation for achieving thinking skills based on cognition, knowledge, and cross section dimensions.

Learning model has a significant students' thinking pattern, which indirectly affects the types of questions raised in the classroom learning. In the RQA class, understand question is more dominant based on the cognitive dimension, which affects the appearance of the conceptual question based on the knowledge dimension. Understand and conceptual question generate classify question based on cross-section dimensions. In the conventional class, remember question is more dominant based on cognitive dimension, which affects the appearance of the factual question based on the knowledge dimensions. Remember and factual question generate the list question based on cross-section dimensions.

The RQA class exhibits excellence in some respects, namely, related to the cognitive dimension, the HOT score is higher and the LOT score is lower than that of the conventional class. In relation with the knowledge dimension, the metacognitive score of the RQA class is three times higher than that of the conventional class. Furthermore related to the cross section between the cognitive and knowledge dimensions the metacognitive score of the RQA class reaches a total frequency of $21.69 \%$ but that of the conventional class only reaches a frequency of $6.36 \%$. This fact suggests that the RQA learning model stimulates the high-order thinking especially metacognitive skills.

\section{REFERENCES}

Anderson, L.W (Ed.).,Krathwohl, D.R (Ed.)., Airasian, P.W., Cruikshank, K.A., Mayer, R.E., Pintrich, P.R., Raths, J., \& Wittrock, M.C. (2001). A Taxonomy for Learning, Teaching, and Assessing: a Revision of Bloom's Taxonomy of Educational Objectives. New York: Longman.

Arends, R.I. (2001). Learning to Teach, Fifth edition. New York: McGraw-Hill Company, Inc

Bahri, A and Corebima, A.D. (2015). The contribution of learning motivation and meta cognitive skill on cognitive learning outcome of students within different learning strategies. Journal of Baltic Science Education. 14(4), pp.487-500

Bahri, A. (2010). Pengaruh strategi pembelajaran Reading Questioning and Answering (RQA) pada perkuliahan fisiologi hewan terhadap kesadaran metakognitif, keterampilan metakognitif, dan hasil belajar kognitif mahasiswa jurusan biologi FMIPA Universitas Negeri Makassar [The effect of Reading Questioning and Answering (RQA) learning strategy on metacognitive awareness, metacognitive skills, and cognitive learning results of the students majoring in biology at animal physiology lecture, State University of Makassar]. Unpub. Thesis. Deptt Biology Education. Universitas Negeri Malang, Malang.

Brookhart, S.M. (2010). How to Assess Higher-Order Thinking Skills in Your Classroom. Virginia USA: ASCD Alexandria.

Coan,S.(2004). Successfull Strategies for Reading in the Content Areas. Grade 3-5. Huntington Beach: Shell Educational Publishing.

Corebima, A.D. (2014). Kajian tentang perkembangan keterampilan metakognitif pada perkuliahan genetika di jurusan biologi FMIPA UM [The study on the development of metacognitive skills in the genetics lecture at biology department at the mathematics and science faculty State University of Malang]. Unpub. Research Report. Universitas Negeri Malang, Malang.

Corebima, AD. dan Bahri, A. (2011). Reading, Questioning, and Answering (RQA): A New Learning Strategy to Enhance Student Metacognitive Skill and Concept Gaining. Discussion paper presented at International Symposium di National Institute of Education Nanyang Technological University, Singapore

Greenstein, L. (2012). Assessing $21^{\text {st }}$ Century Skills: A Guide to Evaluating Mastery and Authentic Learning. USA: Corwin Pubh.

Hariyadi, S. (2015). Evaluasi akademik mahasiswa biologi terhadap perkuliahan genetika di universitas jember [Academic evaluation of biology student to genetics class at the university of Jember]. Jurnal Bioedukasi. 3(2), pp.336-348. 
Hasanuddin. (2013). Pemberdayaan kemampuan berpikir metakognitif melalui pembelajaran Reading Questioning and Answering pada matakuliah taksonomi tumbuhan [The empowerment metacognitive thinking skills through Reading Questioning and Answering learning on plant taxonomy course]. Jurnal Mentari. 16(2). Retrieved from http://ejournal.unmuha.ac.id/index. $\mathrm{php} / \mathrm{mentari} / \mathrm{article} / \mathrm{view} / 131$.

Heer, R. (2009). Taxonomy for learning, teaching, and assessing: a revision of Bloom's Taxonomy of Educational Objectives, Iowa State University Center for Excellence in Learning and Teaching, Retrieved from http:// www.celt.iastate.edu/ pdfs-docs/teaching/ RevisedBloomsHandout.pdf

Insyasiska, D., Zubaidah, S., \& Susilo, H. (2015). Pengaruh Project Based Learning Terhadap Motivasi Belajar, Kreativitas, Kemampuan Berpikir Kritis, dan Kemampuan Kognitif Siswa pada Pembelajaran Biologi [The Effect of Project Based Learning on Learning Motivation, Creativity, Critical Thinking Ability, and Cognitive Ability of Students in Biology Learning]. Jurnal Pendidikan Biologi. 7(1), pp 9- 21.

Khairil. (2009). Potensi model perkuliahan genetika di jurusan biologi fmipa um terhadap kema mpuan metakognisi, kerja ilmiah dan hasil belajar kognitif mahasiswa [The Potential of the models of genetics lecture on the students' metacognitive skills, scientific work, and the cognitive learning results in the biology department of mathemathics and science faculty, State University of Malang]. (Unpub. Dissertation. Deptt. Biology Education. Universitas Negeri Malang, Malang.

Krathwohl, D.R. (2002). A revision of bloom's taxonomy: an overview. Theory Into Practice. 41(4), pp.212-218.

Livingston, J.A. (1997). Metacognition: an overview. Retrieved from http://www.gse.buffalo. edu/fas/shuell/cep564/Metacog.htm.

Magas, C.P., Gruppen, L.D., Barrett, M., Dedhia, P.H., Sandhu G. (2017). Intraoperative questioning to advance higher-order thinking. The American Journal of Surgery. 213(2), pp.222-226.

Mayer, R.E. (2002). Rote versus meaningful learning. Theory Into Practice. 41(4), pp. 226-232

Munzenmaier, C.\& Rubin, N. (2013). Bloom's Taxonomy: What's Old is New Again. Santa Rosa: The eLearning Guild.

Omar, N., Haris, S.S., Hassan, R., Arshad, H., Rahmat, M., Zainal, N.F.A., \& Zulkifli. (2012). Automated analysis of exam questions according to bloom's taxonomy. Procedia - Social and Behavioral Sciences. 59, pp.297-303.

Phillips, A.W., Smith, S.G., \& Straus, C.M. (2013). Driving deeper learning by assessment: an adaptation of the revised bloom's taxonomy for medical imaging in gross anatomy. Academic Radiology. 20(6), pp.784-789

Pintrich, P.R. (2002). The role of metacognitive knowledge in learning, teaching, and assessing. Theory Into Practice. 41(4), pp.219-225

Roini, C.(2012). Kajian miskonsepsi genetika dan upaya mengatasinya dengan pembelajaran peta konsep dan inkuiri terbimbing menggunakan perangkat berpendekatan konsep pada SMA berkategori berbeda [The study of the genetic misconceptions and the attempt to overcome it using concept map learning and guided inquiry supported by concept approach base device in senior high schools with different categories]. Unpub. Dissertation, Deptt. of Biology Education. Universitas Negeri Malang. Malang.

Sumampouw, H. M. (2011). Keterampilan metakognitif dan berpikir tingkat tinggi dalam pembelajaran genetika (artikulasi konsep dan verifikasi empiris) [Metacognitive skills and higher-order thinking, learning skills in genetics course (articulation of concepts and empirical verification)]. Bioedukasi, 4(2), pp.23-39.

Zhakhina, N.M.S.B.B., Kukubaeva, A.K., Smagulov, N.K. \& Kazhibaeva, G.K. (2016). Studying innovation technologies in modern education. International Journal of Environmental and Science Education. 11(14), pp.6512-6517. 
The Comparison of the Question Types in the Rqa (Reading, Questioning, and Answering) Learning Model and Conventional Learning Model

\author{
AUTHORS' BIOGRAPHY

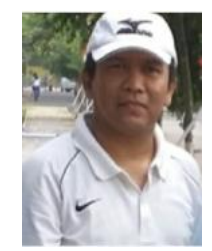 \\ Slamet Hariyadi, M.Si, Postgraduate Student of Universitas Negeri Malang, Indonesia \\ and Lecturer at University of Jember, East Java, Indonesia \\ E-mail: s.hariyadi.fkip@unej.ac.id

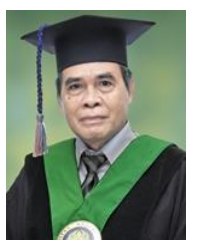 \\ Aloysius Duran Corebima, Professor, at Postgraduate Programe of Universitas Negeri \\ Malang, Malang, East Java, Post code 65145, Indonesia. \\ E-mail: durancorebima@gmail.com \\ Ibrohim, Doctor and Lecturer at Postgraduate Programe of Universitas Negeri Malang, \\ Malang, East Java, Post code 65145, Indonesia.
}

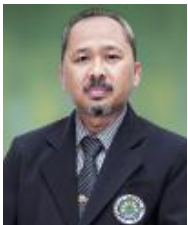

